\title{
Prilog povijesti dubrovačkoga antuninskog roda Kladorubovići
}

Dubrovački antuninski rod Kladorubovići podrijetlom je iz Cernice a ne iz Srebrenice, što je suprotno ponudi Čingrijine genealogije antunina / Vlajkijeve genealogije antunina. Težnja za važnijim podrijetlom roda rezultirala je pogrešnom postavkom. Pronađene informacije o Mirku Pribinjiću Kladorubu povezane su s Cernicom kod Gacka. Ovdje je prezentiranim materijalom skrenuta pozornost na potrebu da se analizira podrijetlo pojedinih obitelji i rodova kao i da se navedeni rod Kladorubovića detaljnije istraži.

Ključne riječi: Vlajkijeva genealogija antunina, Kladorubovići, Mirko Pribinjić zvani Kladorub, Cernica

Rukopis Descrizione delle Origini e Genealogie dei cittadini Ragusei daje prozopografski prikaz izrastanja pučkih obitelji i rodova u okviru dubrovačke Bratovštine svetoga Antuna. Nalazi se u Državnome arhivu u Dubrovniku. Prepoznatljiviji je po naslovu Čingrijina genealogija antunina prema imenu obitelji Čingrija u čijemu se vlasništvu svojevremeno nalazio. Najvažniji među sastavljačima ove genealogije antunina jest dubrovački kancelar Kristo Ivan-Batistin Vlajki (1653. - 1728.) pa se otuda opravdano predlaže da se ovaj rukopis treba ustvari nazvati po sastavljaču a ne po vlasniku i to kao: Vlajkijeva genealogija antunina (skraćeno VGA). ${ }^{1}$ Teško je oteti se ustaljenome nazivu koji je na svojevrstan način urastao u literaturu, ali treba težiti prema uporabi ispravnijega naziva. Ovaj rukopis ima više verzija i razvojnih dopuna. Karakterističan je i po tome da za brojne iznesene informacije ima uporište u izvorima prvoga reda, između ostaloga imenujući ih izrijekom putem precizne signature, sveska i datacije. ${ }^{2}$

Esad Kurtović, Odsjek za historiju, Filozofski fakultet Univerziteta Sarajevo, Franje Račkog 1, 71000 Sarajevo, Bosna i Hercegovina, E-mail adresa: kurtovic.esad@gmail.com

1 Zrinka Pešorda Vardić, U predvorju vlasti. Dubrovački antunini u kasnom srednjem vijeku (Zagreb; Dubrovnik: Zavod za povijesne znanosti HAZU u Dubrovniku i Hrvatski institut za povijest, 2012), 107.

2 Pešorda Vardić, U predvorju vlasti, 14, 37. 
VGA je posebno interesantan, između ostaloga i zato što daje korisne informacije o obiteljima i rodovima podrijetlom iz srednjovjekovne Bosne. U pokušaju da te informacije približimo poznatim tokovima povijesti dubrovačkoga zaleđa, tu se donekle nalazimo pred problemskom osnovom koja je opća karakteristika čitavoga rukopisa. Naime, točno je da se ponuđene informacije u genealogiji antunina mogu sravniti i popunjavati s arhivskim pokazateljima, ali u dovoljnoj mjeri ne i one starije koje se ondje nalaze. Upravo te najstarije informacije detaljnije govore o podrijetlu i teže ih je provjeriti zbog nedostatka kako vezivnih informacija iz zaleđa, tako i prve sačuvane dokumentacije u kojoj bi se pratio njihov prijelaz i snalaženje u novoj sredini. Da ih treba tražiti i da ih ima, to je izvjesno. Na ovome mjestu izdvajamo bitnu dvojbu oko roda Kladorubovića upravo kroz prizmu pitanja njihovoga podrijetla. Na usputan način propitujemo motivacijsku podlogu izbora uvrštenih informacija u VGA-u. Cilj rada jesti poticaj na detaljnije sagledavanje roda Kladorubovića.

Bratovštine su "najstarije laičke duhovne udruge" koje predstavljaju vjersko-humanitarne udruge i u kojima se očituje zajednička pobožnost. Na određenome području bratovštine okupljaju osobe povezane zanimanjem (trgovci, obrtnici ili svećenici), dobnom, društvenom ili etničkom pripadnošću, a s ciljem pomoći i zaštite članova i drugih društvenih slojeva s njegovanjem pobožnosti. Pokazivanje društvenosti, uzajamnoga milosrđa i solidarnosti osiguravalo je članovima bratovštine konkretne doprinose u obogaćivanju kršćanstva svoga vremena, a time i promidžbu u srednjovjekovnoj društvenoj zajednici. Spajanjem Bratovštine Sv. Duha i Sv. Spasitelja s Bratovštinom sv. Petra i sv. Antuna godine 1432. nastala je Bratovština antunina, najuglednija i najvažnija dubrovačka bratovština. Članovi Bratovštine antunina bili su ugledni i bogati pučani, ponajviše trgovci, srednji stalež dubrovačkoga društva. Iako nisu sudjelovali u vlasti, prema svome imetku, profesiji, obiteljskoj strukturi i statusnim simbolima izdvajali su se od brojnijega sitnoga puka i prisvajali naziv "građani" isključivo za sebe. Njihov uzor bila je vlastela, koju su oponašali u svim segmentima pa i u nastojanju da legitimiraju svoju poziciju, gdje je to trebalo, pozivanjem na slavnu i legendarnu prošlost. ${ }^{3}$

Preko Čingrijine/Vlajkijeve genealogije antunina Ruža Ćuk svojevremeno je u postavljenoj preglednoj tabeli rodova podrijetlom iz Bosne navela da se Kladorubovići (od Mirka Pribinjića zvanoga Kladorub), javljaju u Dubrovniku od 1427. godine i da se podrijetlom vezuju uz Srebrenicu, a od Nikole Kladorubovića su

\footnotetext{
3 Zrinka Pešorda Vardić, "Bratimska elita: o počecima dubrovačke bratovštine sv. Antuna”, u: Med Srednjo Evropo in Sredozemljem: Vojetov zbornik (Ljubljana: Založba ZRC SAZU, 2006), 427-442; Pešorda Vardić, U predvorju vlasti, 15 i dalje.
} 
od 1523. godine među antuninima. ${ }^{4}$ Te su informacije nedavno postavljene i u "Popisu antuninskih rodova" Zrinke Pešorda Vardić uz dodatak da je alternativno ime roda Kladarov. ${ }^{5}$ U sadržaju "Genealogije," odakle su crpljene prezentirane informacije za navedene popise i preglede, nalazi se i više informacija koje nisu ni bile predmetom navedenih radova. I inače, vrijeme je pokazalo da su svi uvršteni rodovi prostor za šire i monografske obrade.

Pod Kladorubović, u ponuđenome VGA-u, između ostaloga, navodi se da rod ima podrijetlo iz Srebrenice iz Bosanskoga Kraljevstva (Srebarniza del Regno di Bosna). ${ }^{6}$ Godine 1427. Mirko Pribinjić zvan Kladorub, rodonačelnik ovoga roda, a koji je imao respektabilan status u svojoj sredini (Mircho Pribignich cognominato Cladorub persona nobile, e della corte del re Stefano) sa suprugom Grlicom, kćeri Pribila Krančića iz Srebrenice (Garliza figlia del Pribio Crancich di Srebarni$z a)$, zbog ubojstva je prebjegao u Dubrovnik. Mirko i Grlica imali su dvoje djece, sina Radonju i kćer Vukosavu. U rukopisu VGA dalje se, pored naglašavanja da su postali antunini 1523. godine u doba Nikole Kladorubovića, u ukupnome nizu izdvojenih jedanaest predstavnika roda, linija nasljednika prati se do 1568. godi-

4 Ruža Ćuk, "Dubrovačke građanske porodice poreklom iz srednjovekovne bosanske države", u: Bosna $i$ Hercegovina od srednjeg veka do novijeg vremena (Beograd: SANU, 1995), 182. Iako su ove informacije dane u pratećoj tabeli, u navedenome radu nije posebno tretirana ova obitelj, najvjerojatnije iz razloga što je u razmatranome periodu područje Srebrenice bilo pod vlašću Despotovine i što je to izlazilo iz okvira postavljene teme, Ćuk, "Dubrovačke građanske porodice", 172.

5 Pešorda Vardić, U predvorju vlasti, 41.

6 Origine e genealogia della fameglia Cladorubouich. La fameglia Cladorubouich habe sua origine da Srebarniza del Regno di Bosna, lo attesta l'autrio scrittore dell'origini delle fameglie de cittadini Ragusei quel de Darsa. Dellanno 1427 venne a Ragusa Mircho Pribignich cognominato Cladorub persona nobile, e della corte del re Stefano quale per hauer commesso un homicidio in persona di Vladislauo nobile e barone del medemo re se ne fuggi in Ragusa con Gerliza sua moglie infrascrita, alla quale fece carta dotale di ducati 600 quasi vicino alla sua morte. Nella confraternita di S. Antonio de cittadini Ragusei sula matricola si hora il primo di questa casa l'infrascrito Nicolo Cladorubouich 1523.

1. Mircho Pribignich cognominato Cladorub hebbe moglie Garliza figlia del Pribio Crancich di Srebarniza la qual condusse a Raguse e li fece carta dotale come in Dot. de Notaria 1444: 12 octobre di ducati 600 con la hebbe l'infrascripti figlioli:

Radogna - hebbe moglie e fili come al numero 2. 3.

Vucossaua - fu moglie di Vuchsca Giuricich come per P. li 1443.

2. Radogna Mirchouich figlio di Mircho predicto hebbe per moglie Hiella figlia di Simone de Gallo [točkama označen prazan prostor] Raguseo come per testamento di Marco di Simone de Galo de $1470 \mathrm{f}$. 158 [točkama označen prazan prostor] con la quale hebbe l'infrascritti figlioli

Marco - non hebbe moglie

Simone - hebbe moglie come al numero 4

Nicolo - hebbe moglie e fili come al numero 5.

3. Radogna sopradito doppo la morte di sopradita Hielusa sua prima moglie hebbe la seconda Nicoletta figlia di Mario Tintinich mercante Raguseo come per car. dot. 1465: 6 febraio, con la quale non hebbe figlioli.

Nicolo - bastardo - hebbe moglie e figli come al n. 6 (...) [dalje se prati linija roda do broja $11 \mathrm{u}$ nizu, a kompletan zapis o Kladorubovićima završava:](...) Con la morte di supradicto Dominico di Nicolo Cladorubouich de 1568 diede fine questa fameglia de cittadini doppo il caso di 142 anni, Descrizione delle Origini e Genealogie dei cittadini Ragusei, Hrvatska (dalje: HR) - Državni arhiv u Dubrovniku (dalje: DADU) - Obitelj Čingrija, (Vlajkijeva genealogija antunina) (dalje: VGA), 215-216v. 
ne kada je, kako je i izrijekom istaknuto, poslije 142 godine egzistencije, a podrazumijevajući taj zbroj upravo u dubrovačkome okrilju, ovaj rod bio prekinut (fine questa fameglia de cittadini doppo il caso di 142 anni).?

Upečatljiva prisutnost i de facto citiranje upotrebljavane dokumentacije Vlajkijevoj genealogiji antunina daje elemente istaknutoga povjerenja i vjerodostojnosti. U slučaju roda Kladorubovića to su ipak navodi dokumentacije iz kasnijega vremena, nekako od njihova dolaska u Dubrovnik, pa se za sve ranije navedeno moraju tražiti ili dodatne potvrde ili prihvatljiva kontekstualizacija. Izdvojit ćemo nekoliko navoda koji po našemu mišljenju nisu jasno predstavljeni. Spominjanje Srebrenice u Bosanskome Kraljevstvu 1427. godine samo po sebi nije točno stanje stvari niti je refleks nekoga relevantnog pisanog izvora kojim bi se sastavljač genealogije mogao poslužiti. U to vrijeme Srebrenica je u sastavu Despotovine. ${ }^{8}$ Navedeno bi se onda moglo uzeti kao figurativan odraz rastezljive linije trajanja ili prisjećanja, želje pa i laičkoga logičkog vezivanja. Takvo što imamo i u drugim slučajevima za pojedine rodove, između ostaloga i spominjanje "Hercegovine" prije nego je "ona to bila." Plemićko podrijetlo (persona nobile) Mirka Pribinjića, njegov boravak na dvoru kralja Stefana, gdje je počinio ubojstvo plemenitaša Vladislava i stoga prebjegao u Dubrovnik, su sumnjivi. U prvoj polovici 15. stoljeća u kontekstu poznate povijesti srednjovjekovne Bosne kao i tadašnjih bosanskodubrovačkih odnosa teško je ovdje navedeno adekvatno smjestiti i objasniti. ${ }^{9}$ Dok bosanski kralj Stefan i ubijeni plemić Vladislav otvaraju prostor za nagađanje, eventualnu potvrdu i negaciju, navedeno pojašnjenje "prijelaza" u Dubrovnik krajnje je sumnjiva kontekstualizacija. Dubrovnik je bio azil za brojne predstavnike iz zaleđa, ali ovakav slučaj ubojstva to nije smislenim primjerom, a i da jest, izvjesno bi imao traga u očuvanoj međusobnoj komunikaciji zaleđa i dubrovačke Vlade i, prema poznatome, drugačije bi se završio nego što to rukopis VGA podrazumijeva. ${ }^{10}$

Izneseni raskoraci pokazatelja rukopisa VGA u razumijevanju povijesti prve polovice 15. stoljeća prostor su za detaljnije analize i pretpostavke. Svakako da antunini u oblikovanju svoga rodovskog sustava nisu mogli pronaći slična uporišta kao i dubrovački plemići. Jako im je nedostajala "drevnost" i stoga su na različite

HR-DADU, VGA, 216v.

8 O Srebrenici polazišta u: Mihailo Dinić, Za istoriju rudarstva u srednjevekovnoj Srbiji i Bosni I (Beograd: SAN, 1955); Desanka Kovačević-Kojić, Srednjovjekovna Srebrenica XIV-XV vijek (Beograd: SANU, 2010).

9 Plemićko porijeklo Kladorubovića iz Srebrenice uzima se bez ikakve sumnje, Vinicije B. Lupis, "O rodu Jakete Palmotića”, u: Hrvojka Mihanović Salopek - Vinicije B. Lupis, Željezni duh: Prinos Jakete Palmotića Dionorića hrvatskoj književnoj baštini (Zagreb: Dubrovnik: Institut društvenih znanosti Ivo Pilar, 2010), 27; Vinicije B. Lupis, "Amatus Lusitanus e Didaco Pirro: due ebrei portoghesi e cerchia umanistica di Dubrovnik", u: Humanismo e Ciência: Antiguidade e Renascimento (Aveiro; Coimbra; São Paulo: UA Editora, Universidade de Aveiro; Imprensas da Universidade de Coimbra, 2015), 497.

10 Anto Babić, “Tradicija i istorijsko pravo u odnosima Bosne i Dubrovnika u srednjem vijeku”, u: Pristupni predavanja, prilozi i bibliografija na novite členovi na MANU (Skopje: MANU, 1974), 11-17. 
načine pokušavali popuniti potrebnu prazninu. ${ }^{11}$ Bosansko Kraljevstvo, Srebrenica, kralj Stefan, plemenitost i ubojstvo kao razlog bijega u Dubrovnik i više su nego dovoljan prostor za pojašnjavanje znamenitosti podrijetla ove obitelji. Kako su predstavnici obitelji postali antuninima 1523. godine, ${ }^{12}$ možemo pretpostaviti da se navedene informacije zapisuju u vremenu kada o njima nema mnogo mogućnosti za direktnu provjeru među suvremenicima. Otuda se može pretpostaviti da je navedeno izraz zabilježene usmene predaje, djelomično modificiranih informacija, koje se čuvaju i prenose u krilu roda ipogrešno pročitanih pokazatelja koji su postavljeni pred sastavljača genealogije. Postavlja se i pitanje jesu li Kladorubovići sami koristili arhivske pokazatelje osvojim precima ili su to činili drugi, kao neutralni istraživači.

Naš primarni cilj u prilogu na ovome mjestu skreće u drugome smjeru - ne u pojašnjavanju kako je do toga došlo, iako imamo materijal koji dajemo za zaključnu pretpostavku, nego prema ponuđenome specifičnom nadimku Kladorub / Kladorup, koji se prepoznaje kao olakšani prostor za pronalaženje ovdje spominjane osobe Mirka Pribinjića od kojega poznata povijest roda i potječe. Po svemu sudeći radi se o nadimku koji ima vezu s izrazom drvodjelja. ${ }^{13} \mathrm{Na}$ onome mjestu gdje se poimenično spominje najviše Srebreničana i Dubrovčana povezanih sa Srebrenicom, u detaljnim istraživanjima Desanke Kovačević-Kojić nema adekvatnih uporišta za specifičan nadimak poznatoga rodonačelnika kojega je, ispostavlja se, rodu ostavio Mirko Pribinjić kao prezime (Kladorub-Kladorubović). ${ }^{14}$ Specifičan nadimak nalazi se na drugome mjestu, u današnjoj Hercegovini, u naselju Cernica kod Gacka. ${ }^{15}$ U Vlajkijevoj genealogiji antunina Srebrenica je jedino u slučaju ovoga roda ishodište podrijetla za rod antunina, dok Cernica nije ni za jedan. Prema analizi koja slijedi situacija će biti upravo obrnuta.

Mirko Pribinjić zvan Kladorub, rodonačelnik spominjanih Kladorubovića, nije podrijetlom iz Srebrenice nego iz Cernice. Na to jasno ukazuju prikupljeni podaci. Prema dostupnim informacijama nadimak Kladorub nije uvijek bio sastavnicom njegove identifikacije, što je i uobičajeno stanje s nadimcima kojima je nastanak, održavanje i budućnost potpuno neizvjesna. Naizgled, to bi bio prevelik problem u njegovome pronalaženju i praćenju, no kontekstualizacija je toliko

\footnotetext{
11 Pešorda Vardić, U predvorju vlasti, 110.

12 Nicholo Chladorubouich, HR-DADU, ser. 48. 1, Matrikula antunina (Confraternitates, Matriculae) (dalje: Matrikula antunina), vol. 21, f. 49v.

13 Kladorup / kladorub - drvodjelja, Slavoljub Gacović, Etimologija slovenskih osnova u ojkonimiji Vidinskog sandžaka u XV i XVI veku (Zaječar: 1997), 90-91.

14 D. Kovačević-Kojić, Srednjovjekovna Srebrenica XIV-XV vijek.

15 O Cernici polazište u, Bogumil Hrabak, "Cernica - trg feudalne epohe u istočnoj Hercegovini”, u: Bogumil Hrabak, Iz starije prošlosti Bosne i Hercegovine, knj. IV (Beograd: Arhivar, 2008), 64-109.
} 
upečatljiva da se može pretpostaviti da je riječ o istoj osobi i kada ovaj nadimak nije uz nju spominjan.

U kronološkome nizu ispratit ćemo pronađene pokazatelje kojima se kontekstualizira Mirko Pribinjić zvan Kladorub. U listopadu 1413. godine Mirko Pribinjić i Vukac Bogčić iz Cernice spominju se u razrješenju jednoga trgovačkog društva. ${ }^{16}$ Isti akteri nešto manje od trinaest godina poslije, označeni kao ljudi vojvode Sandalja Hranića Kosače iz Cernice, opet posluju zajedno. U ožujku 1426. godine zadužuju se kod Ivana Teodora Prodanelića na 73 perpera i četiri groša na rok od petnaest dana. Zabilježeno je da je svoj dio duga Mirko Pribinjić vratio tek dvije godine poslije, to jest u veljači 1428. godine. ${ }^{17} \mathrm{U}$ ožujku 1430. godine uz Mirka Pribinjića spominje se, prema poznatome prvi put, i njegov famozni nadimak. Označeni kao kompanjoni, Zavo Baldovinić i Mirko Pribinjić zvan Kladorub iz Cernice (Mircho Pribignich dictus Cladoruph de Zerniza), zadužuju se kod Paskoja Radićievića na iznos od 84 perpera i sedam groša na rok od petnaest dana. ${ }^{18}$ Dokumentima ranijega razdoblja u životu Mirka Pribinjića pripada i spomen u tužbi iz lipnja 1434. godine. Zajedno s izvjesnim Vukcem Miokanićem, Mirko Pribinjić označen kao Mirko Kladorub (Mirchus Cladorub) pojavljuje se kao svjedok za pljačku izvršenu u Bileći. ${ }^{19}$ Njih dvojica u kolovozu iste godine podižu tužbu za pljačku izvršenu u Trebinju. ${ }^{20}$ Daljnji pokazatelji Mirka Pribinjića više vezuju za dubrovačko područje, za trgovinu i vještinu krznara (pelizarius / peliparius). ${ }^{21}$

16 Stoiez Mergich stazionarius facit manifestum quod ipse est solutus integre et satisfactus a Mircho Pribinich et a Vochez Bogzich de Cerniza de omni eo et toto quod ipse habere debebat ab eis et a quolibet ipsorum et imo fecit sibi finem et absolutionem generalem usque ad hanc diem (7.10. 1413.), HR-DADU, ser. 15, Razni zapisi državne kancelarije (Diversa Cancellariae) (dalje: Div. Canc.), vol. 39, f. 305; Esad Kurtović, Arhivska građa za historiju srednjovjekovne Bosne (Ispisi iz knjiga kancelarije Državnog arhiva u Dubrovniku 1341-1526), 2 (Sarajevo: Institut za historiju-JU Historijski arhiv Sarajevo, 2019), 657.

17 Nos Mirchus Pribignich et Vochaç Bochçich\} homines voyuode Sandagl de Zerniza (21. 3. 1426), HRDADU, ser. 10. 1, Dugovi Notarije (Debita Notariae) (dalje: Deb. Not.), vol. 14, f. 11; E. Kurtović, Izvori za historiju srednjovjekovne Bosne I/1 (Ispisi iz knjiga zaduženja Državnog arhiva u Dubrovniku 13651521) (Sarajevo: Akademija nauka i umjetnosti Bosne i Hercegovine, 2017), 94.

18 Nos Zauo Baldouinich et Mircho Pribignich dictus Cladoruph de Zerniza\} socii confitemur quod super nos et omnia nostra bona obligamus nos dare et soluere Pasquoe Radichieuich yperperos octuaginta quatuor et grossos septem usque ad quindecim dies proxime futuros (3. 3. 1430.), HR-DADU, Deb. Not., vol. 14, f. 386; Kurtović, Izvori za historiju srednjovjekovne Bosne I/1, 143.

19 Stanissaus Bogdanouich coram domino Rectore ser Georgio de Goze conqueritur supra Vocighnam hominem Cepregne habitantis in Bilegia. Eo quia dicti Vocighna per vim accepit suprascripto Stanissauo tot cultellos, speculos et didalia quot ascendunt ad sumam yperperorum trium. [Testes:] Mirchus Cladorub, Vochaz Miochanich (9. 6. 1434.), HR-DADU, ser. 21. 2, Tužbe kaznenih djela izvan grada (Lamenta de foris) (dalje: Lam. de foris), vol. 10, f. 201v.

20 Mircus Pribignich et Vuchaz Miochanouich coram domino Rectore ser Johanne de Gondola conqueritur supra Radiuoy Liupsalich, Grubazius barbanum. Eo quia sibi per vim acceperunt unum castratum et unum anulum argenti valoris grossos XX in Trebigne. [Testes] Radasinus Cruchognich, Radoman perlabuch (22. 8. 1434.), HR-DADU, Lam. de foris, vol. 10, f. 257v.

${ }_{21}$ Ad instantiam de Mircho Pribignigh pellizario retulit Lucas riuerius (...) sequestrasse in manibus de Dobrouoy Raspacigh denariis, animalia et quecunque alia que sunt de Radiuoy Raspacigh usque ad jus cognitum inter dictum Mirchum et Radiuoy (25. 10. 1438.), HR-DADU, Div. Canc., vol. 53, f. 30v; Mir- 
Kroz prizmu navedenih pokazatelja izvjesno je da je nadimak Kladorub presudan u razumijevanju podrijetla rodonačelnika Kladorubovića - Mirka Pribinjića Kladoruba iz Cernice. Kroz pokazatelj s nadimkom iz ožujka 1430. godine ne vidi se da je isti označen kao Dubrovčanin niti kao stanovnik Dubrovnika podrijetlom iz Cernice. Njegovo podrijetlo prema VGA-u (persona nobile, e della corte del re Stefano) vjerojatno je iz interesnih potreba djelomično modelirano, kako po temelju dolaska u Dubrovnik, tako i po statusu u Bosni te je tako i zavedeno.

Među suvremenicima Mirka Pribinjića zvanoga Kladorub, rodonačelnika Kladorubovića, jesu braća Radivoj Pribinjić zvan Matorčić (1427. - 1430.) i Vukosav Pribinjić (1412. - 1435.) iz Cernice, koji posluju, između ostaloga, i s Paskojem Radićievićem s kojim je svojevremeno poslovao i Mirko Pribinjić zvan Kladorub. ${ }^{22}$ Oni bi mogli biti i rođaci Mirka Pribinjića. Na ovome mjestu napomenut ćemo i da su Mirko Pribinjić i njegovi nasljednici u različitim poslovnim situacijama bili povezani uz Bogčiće i Miokan(ov)iće iz Cernice.

Povezanost Mirka Pribinjića za Cernicu prati se i u vremenu kada se među informacijama VGA pojavljuju izvori prvoga reda. Primjetno je da se i tada mogu uočiti različita odstupanja. Ono što nedostaje VGA-u može se dopuniti pronađenim arhivskim pokazateljima. Prema pokazatelju iz lipnja 1442. godine rođak Mirka Pribinjića bio je izvjesni Krainić Radulović. Mirko i Krainić sinovi su dviju sestara, a njihovi očevi (možda Pribinja i Radul) bili su pašanci pa su oni bili tetkići. Krainić više nije bio među živima, a iza njega je Mirko Pribinjić, kao najbliži rođak, stekao pravo na njegovo ukopno mjesto koje se nalazilo kod crkve Svetoga Antuna na Pločama, ${ }^{23}$ inače kasnije glavne crkve antunina. Potraga za tetkićem

chus Pribinigh et Colinus del Vetrano, qui dixerunt esse procuratores Liubisse Goysaligh (4. 12. 1440.), Isto, vol. 55, f. 37; Ad instanciam Mirchi Pribinigh ... presentasse Stoyach Coseuigh debitori ipsius Mirchi (7. 3. 1441.), Isto, f. 72 .

22 supra Radissam Pribicich et supra Vucoslauum Pribignich et cum eorum sociis (...) in Cerneza (15. 9. 1412.), HR-DADU, Lam. de foris, vol. 3, f. 10v; Volchossauus et Radiuoi fratres Pribignich de Cernize (21. 5. 1427.), Kurtović, Izvori za historiju srednjovjekovne Bosne I/1, 110; Nos Tichossauus Bratossaglich de Cerniça et Vochossauus Pribignich [prekriženo: de Ragusii]\} sotii (11. 4. 1429.), Isto, 131; Ego Radiuoy Pribignich dictus Matorzich de Cerniza confiteor quod super me et super omnia mea bona obligo me dare et soluere Pascoe Radichieuich yperperos septuaginta sex grossorum Ragusii usque ad quindecim dies (7. 4. 1430.), Isto, 144; Ego Radiuoi Pribignich de Zerniza confiteor quod super me et omnia mea bona obligo me dare et soluere Pascoe Radichieuich yperperos decem et octo et grossum unum (18. 12. 1430.), Isto, 151; Nos Vuchaç Radosalich et Vuchossauus Pribignich de Cerniza (6. 7. 1431.), Isto, 161; Ego Vuchossauus Pribignich de Zerniza (9. 7. 1431.), Isto, 162; Vuchossauum Pribignich de Cerniza (25. 10. 1435.), HR-DADU, Div. Canc., vol. 49, f. 161; Kurtović, Arhivska građa za historiju srednjovjekovne Bosne 2, 1037.

23 Sa strane: Pro Mircho pelipario pro sepultura. Captum fuit quod sepultura Chrainich Radulouich sita ante Eclesiam sancti Antoni extra portam Plozarum attento quod per certas atestationes sumptas et habitas restauit dictum olim Chrainich et quendam eius filium sepultos esse in ipsa sepultura, et nullum alter heredum extare et Mirchum Pribinich peliparium esse propinquum affinem dicto olim Chrainich natum ex duabus sororibus cum ipso Chrainich. Quod dictus Mirchus peliparius cum sepultura habere tenere et 
Krainićem Radulovićem, a i za precima Mirka Pribinjića ovime je nešto šire otvorena.

U listopadu 1444. godine počinju se jasnije dodirivati spoznaje VGA i arhivske građe. Prvi precizan pokazatelj na koji se poziva sastavljač genealogije Kladorubovića vezan je uz miraz kojim je određen brak između Mirka Pribinjića i njegove supruge Grlice (e li fece carta dotale come in Dot. de Notaria 1444: 12 octobre di ducati 600). ${ }^{24} \mathrm{U}$ pronađenome dokumentu o mirazu spominje se Mirko Pribinjić zvan Kladorub, njegova supruga Grlica, njegov punac, tada pokojni Pribil Krančić, kao i visina miraza. Ne spominje se da je Marko Pribinjić zvan Kladorub podrijetlom iz Cernice, ali ni da je podrijetlom iz Srebrenice niti da je njegov punac Pribil Krančić iz Srebrenice, kako se to navodi u VGA-u. Nema ni pratećih "epiteta," to jest isticanja plemenitosti, koju su uz takve osobe iz zaleđa uobičajeno bilježili dubrovački pisari. ${ }^{25}$ Brak Mirka i Grlice odavno je bio sklopljen, a 1444. godine zavedena je ranija primopredaja miraza (quos alias habui a dicto Pribio olim socero meo). Na to upućuje i primopredaja miraza njihove kćeri Vukosave, koja je ranijega datuma. ${ }^{26}$

Početkom studenoga 1443. godine Mirko Pribinjić zvan Kladorub spominjan je u vezi s Cernicom. Mirko Pribinjić zvan Kladorub (Mircus Pribignich dictus Cladorob) i postolar Luka Radetković sklopili su ugovor po kojemu se Mirko obavezao da će vratiti sva dobra Lukinoga nećaka Radašina Brajkovića, koji je umro u Cernici (Radasini Braicouigh, nepotis ipsius Luce Radetcouigh, qui Radasinus mortuus est in Cernica). Cijena Mirkova rada bila je polovica vraćenoga imetka. ${ }^{27} \mathrm{U}$ drugoj polovici studenoga 1443. godine Mirko Pribinjić je među većim brojem sudaca koji su trebali regulirati poslovne odnose između krznara Radovana Medoševića i Radojka Račića, pri čemu je njega delegirao Radovan Medošević. ${ }^{28}$

possidere debeat. Ita tamen quod dictus Mirchus super lapide ipsius sepulture insculpi litteras facere debeat quod dicta sepultura fuit dicti olim Chraynich. Et cum hoc etiam quod saluum sit jus sua unicuique pretendenti jus et rationem habere in et super ipsa sepultura (4. 6. 1442.), HR-DADU, ser. 4, Malo vijeće (Consilium Minus) (dalje: Cons. Min.), vol. 9, f. 91v.

24 HR-DADU, VGA, 215.

25 Ego Mirchus Pribignich dictus Cladorub confiteor quod super me et omnia mea bona pro dote et perchiuio Gherlize uxoris mee filie olim Pribii Chranzich uxoris mee quia computatis denariis hiis quos alias habui a dicto Pribio olim socero meo et hiis quos alias habui a dicto Pribio olim socero meo (...) in ducatis auri sexcentis (12. 10. 1444. g.), HR-DADU, ser. 13. 1, Knjiga o ugovorima i mirazu (Liber dotium Notarie) (dalje: Liber dotium), vol. 6, f. 58v.

26 (25. 1. 1443.), HR-DADU, Liber dotium, vol. 6, f. 38.

27 Mircus Pribignich dictus Cladorob et Lucas Radetchouigh caligarius (4. 11. 1443.), HR-DADU, Div. Canc., vol. 58, f. 108v; Kurtović, Arhivska grada za historiju srednjovjekovne Bosne 2, 1158-1159.

${ }_{28}$ Radouanus Medoseuich peliparius ex una parte et Radoicus Racich ex alia volentes pacifici et quiete sine scriptura et sigura judici de omnibus litibus, discordiis et differenciis existentibus inter ipsos quacumque ratione et causa ad concordium deuenire et expensas euitare sponte et libere se compromiserunt in infrascriptos, videlicet, in Milat Peliocich, Mircum Cladorouich, Dobrie mercatorem, Radiuoi sartorem, Nicolam Braicouich et Radosauum Silcouich ellectos pro parte dicti Radouani et in Radoe Jagodich, Lucam fornarium, Radiç Clichoeuic, Petchum generum Marini Pticich, Radoanum Vlacich caligarium et Milat 
Druge informacije potvrđuju navedenu vezu i djelomično se spajaju s informacijama iz spominjane genealogije antunina. Krajem listopada 1442. godine uz Mirka su navedena dvojica njegovih sinova, Stjepan i Radonja (Stiepani et Radogne), a u vezi sa zalogom srebrnine (pojas i pladanj). ${ }^{29} \mathrm{U}$ travnju 1444. godine podignuta je tužba protiv Mirka Pribinjića i njegovih sinova Radonje i Stjepka (Mirchum Pribinich et eius filium Radognam et Stiepchum) zbog otuđivanja imovine izvršene u Cernici (in Cerniza). ${ }^{30}$ Koncem kolovoza 1444. godine o tome se izjasnilo Malo vijeće tražeći od Mirka pod prijetnjom zatvora da oslobodi braću Miokanić i njihovu imovinu u Cernici, što je sredinom rujna i učinjeno. ${ }^{31}$ VGA spominje Radonju Mirkovića, ali ne i Stjepana / Stjepka Mirkovića kao sina Mirka Pribinjića. Stjepko, sin Mirka Pribinjića sigurno je postojao, a spominje se i u lipnju 1448. godine (Stiepchus filius Mirchi Pribignich) kada oca imenuje za svoga prokuratora. ${ }^{32}$ Stjepko je imao svoje sluge ali i šegrte, što ukazuje na njegovu zasebnu poslovnost. ${ }^{33}$ Ukoliko bi posumnjali u ranije navode o Mirku Pribinjiću i

Braichouich ellectos pro parte Radoichi predicti tamquam in arbitros, arbitratores, amicabiles compositores et comunes amicos (...) (20. 11. 1443.), HR-DADU, Div. Canc., vol. 58, f. 113 bisv.

${ }_{29}^{29}$ Ad instaniam Mirchi Caloian peliçarii et Stiepani et Radogne, eius Mirche filiorum, peliciariorum ... presentasse Milouano Radueuigh lanario unam taciam argenti veterem et paulisper fractam et unam centuram argenti rubeam pro pignore et signo yperperi viginti quattuor et grossis sex. Et eidem Milouano precepisse ut infra terminum octo dierum debeat dicta pignora exigisse alioquin ipsa pignora vendentur ad publicum incantum secundum consuetudinem ciuitatis Ragusii (29. 10. 1442.), HR-DADU, Div. Canc., vol. 57, f. 5v. Otvoreno je pitanje ovdje upotrijebljene riječi: Caloian. Polazišta u, Domagoj Vidović, "Prilog proučavanju odraza svetačkog imena Ivan u hrvatskoj antroponimiji", Rasprave Instituta za hrvatski jezik i jezikoslovlje 35 (2009): 355.

${ }^{30}$ Bratul Miocanich coram domino Rectore ser Nicola de Menze fecit lamentum supra Mirchum Pribinich et eius filium Radognam et Stiepchum, dicens quod ipsi fecerunt sequestrari omnia que habet, videlicet, domum et uxorem et totam massariciam in Cerniza per vaiuodam Stiepanum non habentes secum agere et contra ordines quare etc., osserens se posse ostendenere per unam cartam sibi scriptam per Vocetam Radmilouich contem Cernize (7. 4. 1444.), HR-DADU, Lam. de foris, vol. 17, f. 244v.

${ }^{31}$ Captum fuit quia Mircus Pribignich dictus Cladorub debet usque ad XV dies proxime futuros liberare Vuchaz et Bratugl Miochanich fratres et eius auere ex quod Bratugl predictus detentus fuit in Cerniza cum suo auere ad instantiam dicti Mirci. Et si ad dictum terminum XV dies dictus Mircus non liberauerit dictos Vuchaz et Bratugl cum eorum auere debet stare in carceribus comunis de subtus uno anno continuo (29. 8 . 1444.), HR-DADU, Cons. Min., vol. 10, f. 64v. Prekriženo. Sa strane: Contra Mircum Pribignich; Cassa die XV septembris 1444 de mandato domini Rectori et consilii, HR-DADU, Cons. Min., vol. 10, f. 64v.

32 Stiepchus filius Mirchi Pribignich videndo et non videndo fecit et instituit suum verum et legiptimum procuratorem dictum Mirchum eius patrem ad petendum, exigendum, recipiendum et recuperandum omne id totum et quicquid dictus constituens habere debet et debebit in futurum a quacumque persona quacumque racione et causa (4. 6. 1448.), HR-DADU, Proc. Not., vol. 2, f. 284.

${ }^{33}$ Ratchus Branchouich locauit et acordauit Vuchich eius fratrem, ibi presentem et contentantem, ad standum et habitandum cum Stiepcho Mirchouich conducente ipsum per annos octo (24. 12. 1448.), HR-DADU, Div. Canc., vol. 61, f. 283v; Stiepchus Mirchouich pelizarius conduxit et acordauit Stiepani Vuchsich pro annis quinque proxime futuris ... et ipsum docere artem suam (5. 3. 1450.), Isto, vol. 62, f. 41; Mirchi Pribignich ... Bilosauam famulam dicti Mirchi (25. 6. 1450.), Isto, f. 91; Stiepchus Mircouich pelizarius conduxit et acordauit Mladien Stancouich pro annis quatuor ... ipsum docere artem suam (15. 9. 1450.), Isto, f. 129; Stiepchus Mirchouich pelizarius conduxit et acordauit Radossauum filum Radochne Miloseuich de Berseceua ... ipsum docere artem suam (17.9. 1450.), Isto, f. 131; Stiepcho Mirchouich pelizarius conduxit etaccordauit Radilum Raichouich ... artem bene docere (7. 12. 1450.), Isto, f. 182. 
njegovome sinu Stjepku, jer se nadimak Kladorub uz njih ne navodi, demantirao bi nas pokazatelj iz listopada 1451. godine. Stjepko, sin Mirka Kladoruba, označen i po zanimanju kao krznar (Stiepcho, filio Mirchi Cladorub, pelizario), zajedno s lanarom Božidarom Nikolićem zakupio je od Martina Dobrić(ievića) podrum za svoje poslove. ${ }^{34}$ Prema navodu njegovoga zanimanja kao formuli prepoznavanja nalazimo ga u prosincu 1453. godine kao poslodavca kako uzima za slugu i šegrta Radoja Pribinjića iz Nevesinja na šestogodišnju službu. ${ }^{35}$

Stjepko Mirković umro je prije oca Marka Pribinjića. To se dogodilo prije kraja listopada 1454. godine. Tada je umjesto njega njegov brat Radonja angažiran na isplati zakupa poslovnoga prostora od Martina Dobrića, koji je Stjepko zakupljivao zajedno s Božidarom Nikolićem. ${ }^{36}$ Informacije o Stjepku Mirkoviću i poslije njegove smrti pratimo $\mathrm{u}$ arhivskim vrelima jer je njegova sudbina ostavila traga na obitelj. VGA ne poznaje Stjepka Mirkovića. Kao da je sjećanje na Stjepka Mirkovića nestalo među nasljednicima njegovoga, prema pronađenoj dokumentaciji, poznatijega brata Radonje Mirkovića.

Za razliku od Stjepka učestalije su informacije o Radonji Mirkoviću. U različitim okolnostima Radonja Mirković zabilježen je uz oca Mirka Pribinjića. Još za očeva života Radonja je samostalno istupao kao prokurator, poslodavac koji angažira veći broj slugu i šegrta te se identificira kao meštar krznarskoga zanata i zakupac poslovnoga prostora demonstrirajući poziciju izrasloga autoriteta, ali i materijalno i financijski uznapredovaloga roda. ${ }^{37}$

\footnotetext{
${ }^{34}$ Martinus Dobrichieuich titulo et nomine locationis locauit se et affictauit Stiepcho, filio Mirchi Cladorub, pelizario et Bosidaro Nicolich, lanario, presentibus et ad melius tenendum stipulantibus, recipientibus et conducentibus unam domum ipsius gartini siue stragno positam in ciuitate Ragusii apud furnum heredum condam Marini de Dersa pro uno anno proxime futuro, aut pro duobus aut tribus annis in voluntate dictorum Stiepchi et Bosidari pretio et foro yperperis quadraginta octo quolibet et singulo anno. Quod pretium dicti Stiepchus et Bosidar promiserunt et se obligauerunt ad melius tenendum dare et soluere dicto Martino. Et cum hoc quod pro dicto tempore dicti Stiepchus et Bosidar possit facere et exercere in dicta domo artem lane et ipsam affictare cuilibet primo. Et si dicti Stiepchus et Bosidar facerent aliquod laborerium de lignamine in dicta domo ad eorum voluntatem. Renuntiando omnes (22. 10. 1451.), HR-DADU, Div. Canc., vol. 63, f. 38v.

${ }^{35}$ Stiepchus Mircouich pelizarius conduxit et acordauit Radoe Pribignich de Neuesigne pro annis sex proxime futuris (10. 12. 1453.), HR-DADU, ser. 9, Razne isprave Notarije (Diversa Notariae) (dalje: Div. Not.), vol. 38, f. 171v.

${ }^{36}$ Martin de Dobrich dedit aptai de misericordia soura Radogna Mirchouich de yperperi 24 termene mesi 6 proximi futuri. Renuntiando. I quali denari paga ditto Radogna per affito d'una chasa nella qual stette Stipcho frar del ditto Radogna. E questo se intende per la mitta dela ditta affitason e per laltra mitta de zerchar ditto Martin de Bosidar Nicholich, perche Stipcho e Bosidar achordio insieme la ditta chasa dal ditto Martin sopra ditto (...) (29. 10. 1454.) HR-DADU, Div. Canc., vol. 64, f. 119.

${ }^{37}$ Radogna Mircouich piliparius (12. 4. 1437.), HR-DADU, Div. Canc., vol. 50, f. 187; Ad instantiam de Radogna Mirchouigh pellizarii (16. 11. 1438.), Isto, vol. 53, f. 45v; Liuba, relicta Goychi fecit suum legiptimum procuratorem Radognam Mirchouich peliparium (17. 2. 1439.), HR-DADU, ser. 11, Punomoći notarijata Dubrovnik (Procurae Notariae) (dalje: Proc. Not.), vol. 1, f. 143v; Radogna Mirchouich pellizarius conduxit et accordauit (...) Radincho Goycouich (17. 2. 1440.), HR-DADU, Div. Canc, vol. 54, f. 115v; Radogna Mirchouigh pelparius conduxit et accordauit Iuanem Mirchouigh (29. 9. 1440.), Isto, vol. 55, f11; Radogna Mirchouigh piliparius (30. 11. 1440.), Isto, f. 36v; Radogne Mirchouigh (4. 12. 1440.),
} 
Kladorubovići, Mirko i njegova dva sina Radonja i Stjepko, bili su istoga, krznarskog zanimanja. Prije 1437. godine Mirko Pribinjić imao je mjesto stanovanja u Dubrovniku, a koje je dobio od gradskih vlasti. Prema jednome pokazatelju sa svojim sinom Radonjom Mirkovićem on je te godine svoje mjesto stanovanja dao pod zakup krojaču Radovanu Vlatkoviću. ${ }^{38} \mathrm{Na}$ osnovi istoga pokazatelja teško je znati gdje se to nalazilo. Izvjesno, svoju "gradsku rezidenciju" Kladorubovići su imali u Širokoj ulici, u seksteriju Svetoga Vlahe, inače iz kasnije perspektive procijenjenome popularnom dijelu Dubrovnika među antuninima jer kada Kladorubovići unajmljuju kuću u Dubrovniku, oni tada nisu u toj bratovštini. ${ }^{39}$ Dakle, u listopadu 1447. godine Mirko Pribinjić i njegov sin Radonja Mirković unajmili su pod osmogodišnji zakup kuću u vlasništvu dubrovačkoga vlastelina Ivana Martola Crijevića. Duži zakup i uređivanje kuće pokazuju trajnije namjere obitelji da sebi stvori adekvatan dom u Gradu. Zakup je određen na 35 perpera godišnje. Na sređivanje kuće, nove katove, krov i prozore određena je svota u iznosu od 110 perpera, a koji će se sukcesivno i dijelom odvajati od visine godišnjega zakupa. ${ }^{40}$

Isto, 37; Radogne Mirchouich pelliparii (21. 7. 1444.), Isto, 134v; Radogna Mircouich peliparius conduxit et acordauit Radouanum Crelich (...) et ipsum docere artem (22. 6. 1442.), Isto, vol. 56, f. 137; Ser Dalphinus notarius locauitet acordauit Radogne Mircouich pilipario, ibi presente et conducente, stragnum domus Johannis Marci inqua presentialiter habitant ipse ser Dalphinus ad affictum (...) (6. 8. 1442.), Isto, f. 178; Radogne Mircouigh pellicarius (20. 7. 1443.), Isto, vol. 58, f. 19v; Radogna Mircouich peliparius conduxit et acordauit Radiç Vuchouich (...) docere artem suam (1. 8. 1443.), Isto, f. 29; Brayan Braychouich de Neretua locauit se pro famulo et discipulo Radogne Mircouich (...) et ipsum artem piliparie et varotarie edocere (14. 9. 1444.), HR-DADU, Div. Not., vol. 27, f. 178v; Radogne Mirchouich (22. 8. 1445.), HR-DADU, Div. Canc., vol. 59, f. 43; Mirchi Pribignich (13. 1. 1446.), Isto, f. 144; Mirchi Pribignich (15. 1. 1446.), Isto, f. 145v; Radeglia Dobriseuich fecit et instituit suum legiptimum procuratorem Radognam Mirchouich (9. 8. 1448.), HR-DADU, Proc. Not., vol. 2, f. 196v; Radogna Mirchouich (22. 10. 1452.), HR-DADU, vol. 63, f. $208 \mathrm{v}$.

38 Radogna Mircouich piliparius titulo et nomine locationis dedit et locauit et affictauit domum in qua habitant siue habitauint hactenus cum eius patre et quam domum conduxit a comuni Ragusii, Radoano Vlatchouich sartori, presenti et illam conducenti pro tempore quo ipsam habet a comuni idem Radogna siue dictus eius pater, videlicet, usque XV mensis augusti proxime futuri. Et hoc pro affictuet appensione iperperum trium, quosdictus Radouanus Vlatchouich soluere promisit super se et omnia sua bona dicto Radogna siue dicto eius patri in fine dicti temporis, ad habendum, tenendum, possidendum et habitandum dictam domum usque dictum terminum supra expressum absque contradictione alicuius persone (12. 4. 1437.), HR-DADU, Div. Canc., vol. 50, f. 187.

39 Pešorda Vardić, "Property and Ownership in Dubrovnik's Confraternity of St Anthony in the Late Medieval and Early Modern Ages", In: Towns and Cities of the Croatian Middle Ages: Authority and Property (Zagreb: Hrvatski institut za povijest, 2014), 328; Matko Matija Marušić, "Mapping housing market in late medieval Dubrovnik: The Saint Nicholas sexterium (ca. 1420-1450)", In: Mapping urban changes/Mapiranje urbanih promjena, (Zagreb: Institut za povijest umjetnosti, 2017), 304-306; Irena Benyovsky Latin, Pešorda Vardić, Ivana Haničar Buljan, "Antunini na Placi: prostorni razmještaj članova Bratovštine sv. Antuna duž dubrovačke Place u 15. stoljeću”, Povijesni prilozi 37 (2018), br. 55: 57-138.

40 Sa strane: Locatio ser Johannes de Crieua. Ser Johannes Mart. de Zrieua ex certa eius scientia dedit, comessit et locauit ad affictum Mircho Pribignich et Radogna, filio dicti Mirchi, presentibus et conducentibus usque ad annos octo proxime futuros domus ipsius ser Johannis positam in sexterio sancti Blaxii in Ruga lata apud domum nepotem ipsius ser Johannes. Ad ipsam domum deinceps pro tempore predicto habendum, tenendum, possidendum, gaudendum et usufructandum. Et hoc pro affictu et affictis nomine ipereris XXXV singulo anno soluendorum per ipsos conductorum pro affictu ipse domus. Et hoc etiam pacti expresso quod 
Istoga dana sklopljen je i ugovor sa zidarom Živanom Radojevićem za radove na kući, a već sutradan je Radonja Mirković isplatio prvu ratu zakupa. Zidar je u sljedećih nekoliko mjeseci obavio svoj posao. ${ }^{41}$

Obiteljski posao podrazumijevao je i zakup oranica i vinograda. U kolovozu 1442. godine Mirko Pribinjić i njegovi sinovi Stjepan i Radonja zakupili su posjed na području Župe dubrovačke (petiam unam terre et vinee positis in Breno). ${ }^{42}$ Trajnija orijentacija oca i braće, pa kasnije Radonje Mirkovića, bila je zakup zemlje i vinograda na području Rijeke dubrovačke (in Roxato; terras et vineas in Ombla; in Omlbla in Roxat) kako pokazuju ugovori o zakupljivanju iz1442., 1445., 1455. i 1465. godine te potvrda iz 1471. godine. ${ }^{43} \mathrm{Uz}$ angažman Radonje Mirkovića obi-

ipsi conductores teneantur refici et nouam facere secundum pauimentum ipsius domus et etiam ipsam domum corigi facere ita quod in ipsa domo cadere possit tercium pauimentum. Quod etiam tercium pauimentum de nouo fieri facere teneantur et fenestras lignorum necessarias cum ferramentis oportunis etiam facere teneantur et copertam ipsius que in corectione domus deuastabitur etiam remetti et repperi facere teneantur ita quod bene stet. In quibus quidem laboreriis expendere possint usque ad summam iperperos centum decem dando de ipsis expensis racione ad clarum factum eidem ser Johannem. Et pro quia quidem expensa singulo anno scomputari debeat ipsis cnductoribus affictorum ipsius domus usque ad integra difalcationem ipsius expensum quam reperiri conductores fecissent (10. 10. 1447.), HR-DADU, Div. Not., vol. 32, f. 51v. Sa strane: 1447 de XI octobris. Contrascriptus Radogna Mirchouich contentus fuit quod in defalcatione expensis in fabricatione et laboreris fiendis in domo de qua in contrascripta locationis contet solum schomputum debeant de affictu contrascripto singulo anno iperperis XX et aliis iperperis XV complementi affictus quod singulo anno contrascriptis ser Johannes habere debet. Renuntiando. Judex et testis ut supra, Isto.

${ }^{41}$ Ziuan Radoeuich murator concorditer venit cum Radogna Mirchouich, qui hic de conduxit cum patre suo conduxit ad affictum domus ser Johannes Mart. de Zrieua, existentis in sexterio sancti Blaxii in Ruga larga ad infrascriptam conuencionem et pactum, videlicet, quia ipse Ziuan omnibus suis expensis et custis teneatur corigere et alziare ipsam domum cum muro tantum quantum fuerit beneplacito dicti ser Johannis de Zrieua, patroni ipsius domus. Et quod ipso muro quod faciet inalnando teneatur similiter suis expensis et de lapidibus bonis et sufficientibus de scarpello unam finestram a parte curtini que sit aperta brachio uno cum dimidio et alta brachiis duobus et etiam teneatur facere et ponere in ipso muro ferationis dantes de lapidibus spontatis necessarios et opportunos pro pauimento fiendo in ipsa feratione. Quod quidem laboreriam fuisse teneatur ut supra dictum est per totum presentem mensem octubris et illum laborerum conuenit a pactis fuit de faciendo modo predicto, pro precio et ad racione yperperis triginta trium pro singulo milliari lapidem mensurando iuxta sollitum. Et similiter conuenit conuenit [tako] et promisit copertam ipsius domus suis expensis remouere et postquam completis fuerit murus predictus infra sex dies substenturos reponere suis expensis, videlicet, de magisterio cupis et calcina. Pro quo ipse Ziuan habere debet pro eius mercede et premio iperperis undecim. Hoc semper expresso quod si murus suprascriptus si infra dicte annos subsecuturos postquam completis et creatus fuerit ruynare et cadere venit deffectu et culpa mali laborerii quod tunc ipse Ziuan super se et bona sua teneatur et obligatus sit illum reficere et renouare omnibus suis custis et expensis (10. 10. 1447.), HR-DADU, Div. Not., vol. 32, f. 52. Ispod: Die suprascripta. Predictus Ziuan confessus fuit habuisse a suprascripto Radogna Mirchouich pro parte suprascriptorum laboreriorum yperperis XV. Renuntiando. Judex et testis ut supra. Die XV nouembris 1447. Suprascriptus Ziuan confessus fuit habuisse a suprascripto Radogna Mirchouich dante pro parte suprascriptorum laboreriorum yperperis quindecim. Renuntiando. Judex et testis ut supra. Die III decembris 1447. Suprascriptus Ziuan confessus fuit habuisse a suprascripto Radogna Mirchouich, dante pro parte suprascriptorum laboreriorum iperperis viginti, Isto. Sve prekriženo. Sa strane: Cassa de voluntate partium, Isto.

42 (...) concessit et affictauit (...) Mircho Pribignich et Stipcho et Radogne eius Mirchi filiis pelizariis ... petiam unam terre et vinee positis in Breno apud vineam Nicole de Antibaro et vineam magistri Thome de Anchona medici sallariati comunis Ragusii (...) yperperorum quatuor singulo anno (18. 8. 1442.), HRDADU, Div. Not., vol. 26, f. 87v.

${ }^{43}$ (...) ex terris et vineis (...) concessit et affictauit ... Mircho Pribignich et Stipcho et Radogne eius filiis pelizariis ... petiam unam terre et vinee soldorum sex vel circha positis in Roxato ... pro affictu et affictus 
telj je 1454. godine zakupila zemlju i vinograde i na području Šumeta, u Podstranju i to na duži period. ${ }^{44}$ Tamo je Radonja ugovorio i izgradnju kuće koju je napravio Luka Ivanović. ${ }^{45}$

Mirko Pribinjić zvan Kladorub zajedno sa sinom Radonjom (penes Mirchum Clado ruboeuich et eius filium Radogne) spomenut je u jednome dokumentu o sekvestraciji imovine krajem 1455. godine. ${ }^{46} \mathrm{U}$ više drugih ugovora različite i raznovrsne prirode i sadržaja vidljivo je da je Radonja Mirković djelovao kao glavna poluga u obitelji još za očeva života. ${ }^{47}$ Istaknuto, njegov otac Mirko Pribinjić svojevremeno je poslovao s Vukcem Bogčićem, a sada je Radonja poslovao s Brajulinom Bogčićem iz Cernice, ${ }^{48}$ po svemu rođacima. ${ }^{49}$

nomine yperperorum quinque singulo anno (22. 8. 1442.), HR-DADU, Div. Not., vol. 26, f. 92. Ispod: Die XXVII nouembris 1445. (...) pro affictu aliorum decem annorum, Isto, (...) omnes terras et vineas in Ombla (...) circa soldos sex, pro affictu ... Radogne Mirchouich, (...) pro affictu iperperorum quinque omni anno (23. 1. 1455.), Isto, vol. 39, f. 175v. Sa strane: Die 30 julii 1463. affictum contrascriptum a Radogna Mirchouich pro duobus annis proxime futuris, videlicet, de 1464 et de 1465, finire et quietare, Isto, 176; (...) usque ad annos mille proxime futuros dederunt, concesserunt et locauerunt Radogne Mirchouich (...) soldos quinque et passus viginti tres terrarum (...) in Ombla in Roxat (17. 11. 1465.), Isto, vol. 49, f. 44v; de confirmando et ratificando locatione factam per capitulum canonicorum Radogne Mirchouich de certis terris in Ombla sub die XVII noumbris 1465 (25. 10. 1471.), HR-DADU, Cons. Min., vol. 18, f. 135.

${ }^{44}$ Radogne Mirchouich ibi presente proseet suis heredibus et successoribus (...) usque ad annos sexcentos proxime ... in Zoncheto in loco vocato Podstranie (2. 7. 1454.), HR-DADU, Div. Not., vol. 39, f. 78; Ad instantiam Radogne Mirchouich, (...) per vineam dicti Radogne siue vineas sitam et sitas in Zuncheto (12. 2. 1456.), Isto, vol. 40, f. 139v; (...) Radogne Mirchouich, (...) in Zoncheto inter terrena ipsius Radogne (4. 1. 1457.), Isto, vol. 41, f. 88.

${ }^{45}$ Radogna Mirchouich pilizar fa achordio e pato chon Lucha Yuanouich de Gonchetto, che ditto Lucha li faza chasa in Gonchetto del suo mister, (...) (21. 9. 1454.) HR-DADU, Div. Canc., vol. 64, f. 76v. Dogovorene su mjere, materijal i cijena. Isplate su izvršene 15. 11. 1454. i 25.6. 1455. godine, Isto.

${ }^{46}$ Ad instantiam et requisitionem domini Andree de Drinchas Vitchus riuerius comunis retulit se mandato domini consulis sequestrasse omnes denarios Gluboe Ratchouich de Grauosio qui sunt penes Mirchum Clado ruboeuich [tako] et eius filium Radogne, in manibus eorundem Mirchi et Radogne dicendo quod eos denarios alicui non debeant dare sine licentia, scilicet, eos tenere pro sequestratione donec aliud sibi fuerit ordinatum. Qui Mirchus et Radogna dixerunt ut retulit riuerius quod erat verum quod habebant de denariis dicti Gluboe et tenent eos pro sequestratione (22. 12. 1455.), HR-DADU, Div. Not., vol. 40, f. 108.

47 Radogne Mircouich (19. 9. 1448.), HR-DADU, Div. Canc., vol. 33, f. 30; Radogna Mirchouich (13. 3. 1451.), HR-DADU, Div. Not., vol. 36, f. 86; Radogna Mircouich (7. 12. 1453.), HR-DADU, ser. 3. 1, Vijeće umoljenih (Consilium Rogatorum) (dalje: Cons. Rog.), vol. 13, f. 266v; Radogna Mircouich (17. 12. 1454.), HR-DADU, Div. Not., vol. 39, f. 161v; Radogna Mircouich (1. 3. 1455.), Isto, f. 199; Radogne Mircouich (17. 12. 1456.), HR-DADU, Div. Canc., vol. 66, f. 42; (3. 1. 1457.), Isto, f. 56v; (9. 3. 1457.), Isto, f. 102; (30. 3. 1457.), Isto, f. 113v; (24. 10. 1458), Isto, vol. 68, f. 4v; (6. 6. 1459.), Isto, f. 68; (23. 6. 1459.), Isto, f. 151; (4. 11. 1460.), Isto, vol. 69, f. 172.

${ }^{48}$ Ego Braiulinus Bogcich de Cerniza confiteor quod super me et omnia mea bona obligo me dare et soluere Radogne Mircouich pilipario yperperos quadraginta ad omnem voluntatem dicti creditoris. Et sit de presenti viagio et si ultra etc. Renuntiando etc. Hec autem etc. Judex et testis ut supra (5. 2. 1446.), HR-DADU, Div. Not., vol. 31, f. 16. Pogrešno pročitano kao Marković u: Kurtović, Izvori za historiju srednjovjekovne Bosne I/1, 267.

49 (...)Vocaz Bogcich et Braiulinum nepotem dicti Vochaz (...) in Cerniza (1. 4. 1436.), HR-DADU, Lam. de foris, vol. 11, f. 79v. 
Koncem 1459. godine Mirko Pribinjić zakupio je kuću Nikole Božićkovića na tri godine.$^{50}$ To je posljednja informacija o Mirku kao živome, a koja je pronađena za potrebe ovoga priloga.

Genealogija antunina ne spominje kada je Mirko Pribinjić umro niti njegovu oporuku. Nepoznavanje oporuke vjerojatno je razlogom nepoznavanja svih potomaka Mirka Pribinjića. Oporuka Mirka Pribinjića sastavljena je na samome početku 1461. godine, a već je sljedeće godine objavljena i prepisana, što bi značilo da je Mirko Pribinjić u međuvremenu umro. Ovdje prezentirani pokazatelji o njegovome životu kreću se u periodu od 1413. do 1461. godine. Oporuka nudi veći broj informacija koje ne samo da obogaćuju prozopografiju Kladorubovića, nego daju i pojašnjenja koja se tiču njihove budućnosti.

Svoju suprugu Grlicu Mirko Pribinjić ne spominje u oporuci, što bi ukazivalo da ona tada više nije među živima. Od nasljednika navodi kćer Dominiku te sinove Radonju i Stjepka/Stjepana (Stefan/Stipko). Radonja i Stjepko imaju nasljednike, a imenom su spomenuti i Stjepkova žena Vukuša (Vuchuxa/Vuchosa) i njihov sin Petar. Prema oporuci Stjepka više nije bilo među živima, a na specifičan način za njegovu suprugu i nasljednike po oporuci Mirka Pribinjića brinut će se drugi njegov sin Radonja. Stjepkovim nasljednicima određena je jedna kuća u seksteriju Svetoga Nikole. Dodatno, Stjepkova supruga i djeca imat će jednu sobu u kući Mirka Pribinjića, budućoj Radonjinoj kući, a u trajanju od pet godina. Po isteku toga perioda, kada budu morali napustiti Radonjinu kuću, tada je Radonja bio obavezan da im osigura novčani iznos od 150 perpera. Također, Radonja je trebao Stjepkovim nasljednicima osigurati i dio kućnoga namještaja. Posebno je Mirko za Stjepkove nasljednike oporukom ostavio svoj krevet s posteljinom, ikonu i kovčeg sa svojom odjećom. Na kraju je Mirko imenovao skrbnike (tutore) da se brinu za nasljednike njegova sina Stjepka (Šime Stojaković, Radiša Gojčić i Mirkov sin Radonja Mirković). Stjepkova supruga Vukuša zadržavala je ono što je sama posjedovala, a dugovi njezina supruga Stjepka prelazili su u obavezu njegovoga brata Radonje. Eventualni Mirkovi dužnici dalje duguju Radonji, a iznimno dug Vukše Đuričića pripada popola Radonji i Stjepkovim sinovima. Istaknuto je da Mirko Stjepkovome sinu Petru ostavlja svoj srebrni pojas. Pored silnih obaveza Radonja je dobio spomenutu kuću u kojoj su živjeli Kladorubovići, a u oporuci je naglašeno da njemu pripada i zakupljeni posjed u Šumetu. ${ }^{51}$

\footnotetext{
${ }^{50}$ Nicola Bositchouich locauit et affictauit unam eius domum positam in Ragusio in Sesterio sancti Nicole apud domum Marci de Stai, Marco Pribignich lanario, ibi presenti et conducenti pro annis tribus proxime futuris, incepturis die XII augusti proxime futuri de 1460. Pro quibus annis tribus dictus Nicola dixit et confessus fuit sibi integraliter et in totum solutum et satisfactum esse pro affictu dicte domus. Et quod dictus Nicola soluere debeat illud quod soluitur pro terreno dicte domus (19. 12. 1459.), HR-DADU, Div. Not., vol. 43, f. 38.

${ }^{51}$ Testamentum Mirchi Pribignich. $M^{\circ} C C C C^{\circ} L X I I^{\circ}$, indictione X, die X mensis februarii, Ragusii. Hoc est testamentum Mirchi Pribignich (...) dicto testamento tenoris infrascripti, videlicet: In Christi nomine amen.
} 
Izdvojene informacije obogatile bi genealogiju da je sastavljač VGA imao oporuku pred sobom. Na ovome mjestu pretpostavljamo da sastavljač rodoslovlja Kladorubovića možda nije prema nazivu oporuke prepoznao da se radi o Mirku Pribinjiću Kladorubu jer u naslovu, a i u oporuci, specifični nadimak nigdje nije upisan. Međutim, to nije jedina moguća pretpostavka. Pored Stjepka i njegove linije rođaka (supruga Vukuša i sin Petar), koje VGA ne poznaje, tu je i Mirkova kći Dominika, koju VGA ne navodi, a koja nije zabilježena samo u oporuci svoga oca. Dominika, kći Mirka Pribinjića, sestra Radonje i Stjepka Mirkovića, bila je redovnica samostana Svetoga Nikole. Koncem studenoga 1487. ona je pridodana na listu tutora nasljednika svoga brata Stjepka Mirkovića. ${ }^{52}$ Početkom prosinca 1489. godine njezina pozicija kontekstualizirana je novim informacijama. Dominika je spomenuta kao Simonova nasljednica, sina njezinoga brata, tada pokojnoga Radonje Mirkovića i njegove prve supruge Jele (Jeluše). Tada je spomenuta i Dominikina kći Katarina, Katarinin suprug Stanač Miokanović i njihov sin Dominik te Dominikin unuk i praunuk Mirka Pribinjića Kladoruba. ${ }^{53}$ U ožujku 1492. godine uz kćer Katarinu i zeta Stanača Miokanovića Dominika je navedena kao kći Mirka Pribinjića Kladoruba (filiam olim Mirchi Cladorub), a kao rođakinja i nasljednica Radonje i Simona Kladorubovića (tanquam propinquam et

1461 adi 5 genaro. Io Mircho Pribignich essendo infirmo della persona et sano dela mente per la gratia de Dio fazo et ordeno mio ultimo testamento. In prima lasso pro dezima et primizia a sancta Maria magior de Ragusa yperpero uno, item lasso a sancto Lazaro yperpero uno, item lasso a domino Marcho, padre mio spiritual, yperpero uno, item a domino Michoie Luxich lasso yperpero uno. Item lasso a Dominica fiola mia che prega Dio per mi yperperi 2. Item lasso alli heredi di Stefano mio fiol una caxa in sester di San Nicola, apresso chaxa di Dobros fo fante de ser Matio de Gradi. Item lasso e voglu che Vuchuxa muglier di Stefano possa habitar in una chamera in qual piaxera a Radogna chon li sui fioli credi anni 5 chon Radogna mio fiol, e quando se vorano partir de casa mia, compiando anni 5, come deto di sopra, che Radogna sia tegnuto subito dar ali heredi de Stipcho, mio fiol yperperi 150, zoie, yperperi cento cinquanta. Item lasso che Radogna mio fiol sia tegnuto dar parte dela masarizia de chasa ali eredi de Stipcho sopra sua chonscientia. Item lasso ali sopraditi eredi de Stipcho leto mio fornito piuma chouertor e altro che partien alo leto, item una inchona in chamara mia lasso alli sopraditi heredi e una chassa deli mei vestimenti. Item lasso todori ali heredi de Stipcho mio fiol, Radogna fiol mio, Radixa Goizich, Simum Stoiachouich barbir che gouernano sopraditi heredi. Item [1] lasso a Radogna mio fiol la chaxa mia in la qual habitamo al presente, item voglu che quela afitaxion che a fato Radogna a suo nome, zoie, in Zoncheto che sia in soa liberta che io non voglio che se intenda mio niente de quela afitaxion. Item voglio quelo che auera Vuchosa moglier de Stipcho del suo ouer in potesta soa, che li sia in sua liberta. Item voglio se se trouara algun debito de Stipcho, fiol mio, ouer de Radogna, voglio che paga Radogna debiti de tuti dui. E se se trouara algun debitor mio ouer oblega voglio che schuoda Radogna, reseruando lo debito de Vuchxa Guricich, la mita a Radogna e l'altra la mita ali fioli de Stipcho. Item se se trouara de pur che a mi partenesse lasso a Radogna fiolo mio. Item lasso a Petar, fiol de Stipcho, mia centura d'argento per amor. Fazo epitropi mei a satisfacta parte mio testamento Radogna, mio fiol, Simicii Stoiachouich barber e che li sia recommandata la anima mia. (...) [1v] (10. 2. 1462.), HR-DADU, ser. 12. 1, Oporuke Notarije (Testamenta Notariae) (dalje: Test. Not.), vol. 18, f. 1-1v. ${ }^{52}$ (...)Dominica, reclausa sancti Nicolai (...) additi fuerunt tutoris aliis tutoribus alias factis heredibus quondam Stipchi Mirchouich (27. 11. 1487.), HR-DADU, Cons. Min., vol. 23, f. 97v.

${ }_{53}$ appellationem interpositam per Dominicam reclausam monasterium Sancto Nicolao, tanquam succetricem bonorum Simonis Radogne Mirchouich, heredis quondam Jelusse matris sue et prime uxoris quondam Radogne Mirchouich predicti et Catherinam, filiam dicte Dominice et uxori Stanacii Miochanouich et ser Jacobum Mat. de Getaldi, procuratorem dicti Stanacii et procuratorem dicti Dominici, filii dicte Catherine ab una sententia (...) (4. 12. 1489.), HR-DADU, Cons. Min., vol. 23, f. 242v. 
succetricem condam Radogne et Simonis Cladorubi). ${ }^{54}$ Po svemu je Dominika bila važna spona u rodu Kladorubovića poslije svoga brata Radonje Mirkovića. Svoju oporuku Dominika, redovnica dominikanka, sačinila je u ožujku 1505. godine. Spomenuta je kao preminula 1516. godine, a nasljednik njezinih dobara je pripadnik loze Kladorubovića - barberius Nikola Kladorubović. ${ }^{55}$

Za razliku od Dominike VGA zna za Vukosavu, kćer Mirka Pribinjića. Može biti da Vukosava nije bila među živima i stoga nije bila uvrštena u oporuku. O njoj ne znamo ništa, ali bolja je situacija s njezinim suprugom, ponajviše jer je isti bio poslovno povezan s njezinom obitelji. Ta se veza mora podrobnije ispratiti. U jednoj tužbi spočetka svibnja 1443. godine Radonja Mirković označen je kao prokurator "izvjesnoga" Vukše Đuričića i u tome je svojstvu podigao tužbu protiv više osoba zato što su njegovoga "poslodavca" Vukšu opljačkali u Cernici (tkanine i novac u ukupnoj vrijednosti od 120 perpera). Radonja je zasebnu tužbu podigao i protiv Vukšinoga brata Radoslava Đuričića zbog prizivanja na tamošnji domaći sud. ${ }^{56}$ Nekoliko dana prije tih tužbi na zahtjev prokuratora Radonje Mirkovića izvršeno je oduzimanje od pekara Stojaka jedne zadužnice (za drvo) dužnika Radosava Đuričića. Sa strane ove sekvestracije dopisano je da je inkasirana Mirkovom voljom, Radonjinim ocem. ${ }^{57}$ Navedena braća Vukša i Radoslav Đuričić poznata su po trgovini u dubrovačkome zaleđu. Početkom siječnja 1439. godine osnovali su trgovačko društvo $s$ Radišom Petkovićem. Braća su uložila 245 perpera, a Radiša 80 perpera, ali pored zajedničkoga ulaganja novca društvo

\footnotetext{
${ }^{54}$ appellationem interpositam per Dominicam filiam olim Mirchi Cladorub, tanquam propinquam et succetricem condam Radogne et Simonis Cladorubi et Catherinam, filiam dicte Dominice, uxorem Stanacii et dictum Stanaciium, tanquam maritum dicte Catherine ab una sententia (...) (26. 3. 1492.), HR-DADU, Cons. Min., vol. 24, f. 145.

${ }^{55}$ Nicolaus Radognich barberius dictus Cladorubouich legatarius et beneficiatus in testamento quondam Dominice monialis terci ordinis sancti Dominici, filie quondam Mirchi Pribignich de omnibus bonis tam stabilibus quam mobilibus dicte quondam Dominice ut apparet in dicto testamento de quo constat in Testamentis Notarie in 1505, die III martii a carta 97, et tamquam cessionarius in bonis et super bona quondam Simchi Radogne Mirchouich dicti Cladorubouich de yperperis centum viginti per quatuor potestates sibi datas ad sententiam arbitrariam de qua constat in Diuersis Notarie in 1505, die VIIII octobris a carta 182, (...) (22. 10. 1516.), HR-DADU, Div. Not., vol. 93, f. 61-61v.

${ }_{56}$ Radogna Mircouigh tanquam procurator Vuxe Giuricigh coram domino Rectore ser Nicola Matei de Georgio fecit lamentum supra Vucettam Radmilouigh et Braiulinum Boghcigh, Radouanum Tuerdisaligh, Vuxam Vlatcouigh, Milissam Petcouigh, Radoe Ticosaligh et Radoe Radisigh, dicens quod ipsi accusati insultauerunt ipsum Vuxam Giuricigh in Cerniça et per vim arripuerunt sibi pannos et denarios usque ad summam yperperis centum viginti. [Testes:] Vucaç Miocagnigh, Radan Tuerdisaligh" (9.5. 1443.), HR DADU, Lam. de foris, vol. 16, f. 202v; „Radogna Mircouigh tanquam procurator Vuxe Giuricigh coram domino Rectore ser Nicola Matei de Georgio fecit lamentum supra Radosauum Giuricigh eius fratrem, dicens quod ipse Radoslauus Giuricigh citari fecit ipsum coram judicio Sclauorum. [Testes:] Vucaç Miocagnigh, Radan Tuerdisaligh, Isto, 203. I ovdje ćemo potcrtati da se među optuženima i svjedocima spomnju Brajulin Bogčić i Vukac Miokanić, koji se uz Pribinjiće-Kladoruboviće češće spominju na cerničkome području.

${ }^{57}$ Ad instantiam Radogne Mircouigh pelliçarii (...) sequestrasse in manibus de Stoiach fornario unam credentiarum ligni que est Radosaui Giuricigh (...) (3. 5. 1443.), Div. Canc., vol. 57, f. 224v. Prekriženo. Sa strane: Cassa de voluntate Mirchi, patris Radogne, qui est procurator etc., Isto.
} 
je podrazumijevalo i odlazak svih aktera "na teren" (ad viagium) radi trgovine $\mathrm{i}$ oplodnje uloženoga kapitala. ${ }^{58}$ Braća Đuričić povezana su s Mirkom i njegovim sinom Radonjom. Ako ponovno zavirimo u VGA, pod Kladorubovićima uočit ćemo da je spomenuti Vukša Đuričić ondje naveden zapravo kao suprug Mirkove kćeri i Radonjine sestre Vukosave (Vucossaua - fu moglie di Vuchsca Giuricich), odnosno da je u slučaju dvije tužbe i sekvestracije iz svibnja 1443. godine Radonja Mirković istupao u ime svoga tadašnjeg zeta Vukše i njegovog brata Radoslava. Vukša Đuričić je i nešto ranije opljačkan u Cernici gdje je imao svoju trgovinu. Tužba je podignuta u rujnu 1442. godine ${ }^{59}$ Inače, Vukša Đuričić službeno je imao Vukosavu kao suprugu prije siječnja 1443. godine kada je punac Mirko odredio miraz u iznosu od dvjesto perpera dubrovačkih dinara. ${ }^{60}$ Činjenica da je samo Vukša Đuričić spomenut u oporuci Marka Pribinjića (1461.) definitivno bi moglo značiti da njegova supruga Vukosava tada nije bila među živima. ${ }^{61}$ Po svemu sudeći i Vukša Đuričić podrijetlom je iz Cernice. ${ }^{62}$

Stjepko Mirković umro je prije 1454. godine. Za njegove nasljednike brinuli su se tutori koje je oporukom imenovao njegov otac Mirko Pribinjić. Tako u travnju 1465. godine tutori Stjepkovih nasljednika (tutoribus heredum Stiepchi Mirchouich dicti Cladorub pellizarii) odobravaju za njegovu kćer Ružu novčana sredstva za miraz prilikom njezine udaje. ${ }^{63}$ VGA ne poznaje ni Ružu, kćer Stjepka Mirkovića i unuku rodonačelnika Kladorubovića, Mirka Pribinjića Kladoruba. Pokraj sina Petra, spomenutoga u oporuci djeda Mirka Pribinjića, Stjepko Mirković imao je i sina Paskoja, a zajedno s majkom oni su spomenuti 1470. godine prilikom imeno-

\footnotetext{
58 Vochxa Giuricigh et Radosauus eius frater pro una parte et Radissa Petchouich pro alia parte fecerunt societatem insimul. In hunc modum quod dictus Vochxa de denariis ipsius et dicti Radosauus fratris sui debeat ponere in dicta societate et collegantia yperperos ducentos quadraginta quinque grossos et dictus Radissa debeat ponere yperperos octuaginta. Et cum dictis denariis debeant ire ambo insimul ad viagium et mercari et trafigare quod melius scient et poterunt pro lucrando (...) (5. 1. 1439.), HR-DADU, Div. Canc., vol. 53 , f. 72 bis.

${ }_{59}$ Radasinus Braicouich et Vuxa Giuricich socii, coram domino Rectore ser Jacobo de Georgio fecerunt lamentum supra Radanum Tuerdisalich, dicentes quod ipse venit et aperuit eorum apotecam in Cerniza sine eorum scire et furati fuit eorum libris XXX cere (...) (20. 9. 1442.), HR-DADU, Lam. de foris, vol. 16, f. 14.

${ }^{60}$ Ego Vuchsa Giuricich confiteor quod super me et omnia mea bona pro dote et perchiuio Vuchossaue filie Mirchi Pribinich uxoris mee habui et recepi ab ipso Mirco socero meo mihi dante et soluente iperperos ducentos grossorum pro dote et perchiuio predictis (25. 1. 1443.), HR-DADU, Liber dotium, vol. 6, f. 38.

${ }^{61}$ lo debito de Vuchxa Guricich (10. 2. 1462.), HR-DADU, Test. Not., vol. 18, f. 1v.

${ }^{62}$ Možda se na njega odnose i kasnije informacije: in fauorem Marie relicte Vlacusse Giuricich (2. 8. 1479.), HR- DADU, Cons. Min., vol. 21, f. 80; Mariam relictam Vlacusse Giuricich (26. 10. 1482.), HR-DADU, Cons. Rog., vol. 24, f. 111v-112; (2. 11. 1482.), Isto, 113v; Marie relicte Vlachusse Giuricich (2. 8. 1485.), HR-DADU, Cons. Min., vol. 22, f. 240; Marie relicte Vlachusse Giuricich (17. 2. 1491.), Isto, vol. 24, f. 49v.

${ }_{63}$ Captum fuit de dando libertatem tutoribus heredum Stiepchi Mirchouich dicti Cladorub pellizarii quod pro maritatione et dote Ruxe, filie dicti olim Stiepchi possint promittere et dare de bonis tutorie eorum in usque ad summam iperperorum tercentorum (4. 4.1465.), HR-DADU, Cons. Min., vol. 16, f. 210.
} 
vanju tutora sinovima Stjepka Mirkovića. Među tutorima je njihova majka Vukuša, ali i njihov stric Radonja Mirković. ${ }^{64}$ Uz jamstvo sina Nikole da će novac vratiti kada za to bude potreba, Radonja Mirković se u kolovozu 1479. godine poslužio sredstvima ostavljenima za nasljednike njegovoga brata Stjepka Mirkovića. ${ }^{65}$

\begin{abstract}
$* * *$
Istaknutu poziciju u rodu Kladorubovića, koju je Radonja Mirković izgradio za života oca Marka Pribinjića, dodatno osnažena očevom oporukom, nastavljena je i u kasnijemu vremenu. Raznolike su poslovne i društvene situacije u kojima se on sve nalazi, a pored patronima Mirković uz njega se spominje i nadimak Kladorub, kojim se obiteljska linija dodatno osnažuje. Radonja Mirković spominje se u više navrata u arhivskim vrelima, ${ }^{66}$ osobito u knjigama zaduženja ( 1460. - 1479.). ${ }^{67}$ Time su okviri života Radonje Mirkovića skicirani zasad poznatim vremenskim periodom 1437. - 1481. godine. ${ }^{68}$
\end{abstract}

64 Ser Paulus Ni. de Poza, ser Clemens Mar. Ra. de Goze, ser Franciscus Pau. de [tako], Radogna Mirchouich, Matchus Pechouich, Anonius Bachrouich, Vochussa uxor Stiepchi Mirchouich [pridodato: Migl Radossalich] [pridodato: ser Petrus Mar. de Menze additus fuit die 17 maii 1487]\} facti fuit tutores Pasqualis et Petri filiorum olim Stiepchi Mirchouich cum libertate et auctoritate consuetis (24. 11. 1470.), HR-DADU, Cons. Min., vol. 18, f. 61.

${ }^{65}$ Captum fuit de dando Radogne Mirchouich denarios qui sunt in camera in quos ipse fuit positus in pagamentum per curam dominorum consilium. Cum hoc quod teneatur dare plegiariam de restituendo ipsos denarios in cameram quando quereretur per filios olim Stiepchi Mirchouich aut per alios habentes melius jus quam ipse Radogna in dictis denariis. Nicola filius suprascripti Radogne plegius pro suprascripto Radogna (20. 8. 1479.), HR-DADU, Cons. Min., vol. 21, f. 85.

${ }^{66}$ Radogne Mirchouich (29. 5. 1461.), HR-DADU, Div. Canc., vol. 70, f. 82; (21.8. 1461.), Isto, f. 114; Radognam Mirchouich (25. 9. 1461.), HR-DADU, Proc. Not., vol. 3, f. 146v; (22.6. 1462.), HR-DADU, Cons. Min., vol. 16, f. 15v; (10.2. 1463.), HR-DADU, Div. Canc., vol. 71, f. 1v; Radogna Mirchouich (6. 10. 1463.), HR-DADU, Cons. Min., vol. 16, f. 96; (21.7. 1464.), HR-DADU, ser. 2, Veliko vijeće (Consilium Maius), vol. 12, f. 175; (4. 12. 1465.) HR-DADU, Div. Not., vol. 49, f. 53v; (9. 9. 1466.), Isto, vol. 50, f. 65; (13. 10. 1466.), Isto, f. 75; Radogna Mirchouich dicto Clodorab [tako] (20. 10. 1466.), Isto, vol. 49, f. 150v; (22. 10. 1466.), Isto, vol. 50, f. 79; (4. 11. 1466.), Isto, f. 83; (19. 11. 1466.), Isto, vol. 49, f. $163 \mathrm{v}$; (4. 5. 1467.), Isto, vol. 50, f. 138v; (13. 8. 1468.), Isto, vol. 53, f. 89v; (4. 12. 1468.), Isto, vol. 52, f. 81; Radogna Mircouich dictus Cladorub (3. 12. 1468.), HR-DADU, Lam. de foris, vol. 40, f. 272v. Sa strane: Die XV aprilis 1469. Radogna Mircouich, Isto; (13. 3. 1469.), HR-DADU, Cons. Min., vol. 17, f. 215; (25. 5. 1469.), Isto, f. 231; (14. 6. 1469.), HR-DADU, Div. Not., vol. 52, f. 159; (21. 6. 1469.), Isto, vol. 53, f. 187; (27. 6. 1469.), Isto, 189; (17. 8. 1469.), Isto, vol. 52, f. 188; (24. 11.1470.), HR-DADU, Test. Not., vol. 20, f. 158; (25. 10. 1471.), HR-DADU, Cons. Min., vol. 18, f. 135; (24. 11. 1472.), Isto, f. 224; (9. 1. 1473.), Isto, vol. 19, f. 2; (24. 4. 1473.), Isto, f. 26; (6. 5. 1474.), Isto, f. 122v; (22. 5. 1476.), Isto, vol. 20, f. 58.

${ }^{67}$ Radogne Mirchouich (7. 8. 1460.), HR-DADU, Deb. Not., vol. 34, f. 175. Pogrešno pročitano kao Marković u: Kurtović, Izvori za historiju srednjovjekovne Bosne I/1, 318; Radogna Mirchouich dictus Cladorub lanario (25. 9. 1469.), Kurtović, Izvori za historiju srednjovjekovne Bosne I/1, 331; Radogne Mircouich (1. 3. 1470.), Isto, 133; Radogna Mirchouich dictus Cladorub lanarius (16. 8. 1470.), Isto, 342; Radogna Mirchouich dictus Cladorub de Ragusio (17. 7. 1472.), Isto, 371; Radogna Mircouich dictus Cladorub (poslije 30. 9. 1472.), Isto, 373; Radogne Mirchouich lanario (9. 2. 1474.), Isto, 384; Radogne Mirchouich lanario (16. 2. 1474.), Isto, 384; Radogne Mirchouich (14. 3. 1474.), Isto, 175; Radogne Mirchouich (24. 11. 1474.), Isto, 394; Radogne Mirchouich (10. 4. 1475.), Isto, 396; Radogna Mircouich dictus Cladorub (9. 11. 1475.), Isto, 402; Radogna Mirchouich dictus Cladorub (12. 7. 1476.), Isto, 411; Radogna Mircouich dictus Cladorub (23. 9. 1477.), Isto, 427; Radogna Mirchouich dictus Cladorub (15. 3. 1479.), Isto, 450.

$68 \mathrm{Na}$ braću Stjepka i Radonju opravdano aludira pokazatelj iz 1475. godine: Prima pars est de induciando pro male lata sententiam appellatam per tutoris heredum Stiepchi Mirchouich contra Radognam 
Prema VGA-u Radonja Mirković zvan Kladorub dva puta se ženio. Spomenuli smo prvu suprugu Jelu (Jelušu) i njezinoga sina Simona. S drugom ženom Nikoletom, kćeri Marka Tintinića, ${ }^{69}$ Radonja nije imao djece, ali je imao izvanbračnoga sina. Među njegovim nasljednicima spominje se prezime Radonić/Radonjić kao patronim, ali prezime Kladorubović prevladalo je u kasnijim pisanim vrelima. ${ }^{70}$ Prije nego su Kladorubovići postali antuninima, Nikola Kladorubović bio je

$\overline{\text { Mirchouich (17. 6. 1475.), HR-DADU, Cons. Rog., vol. 22, f. } 211 \text { v. Na ovome mjestu pretpostavljamo da }}$ su mogući razlozi izostajanja obiteljske linije i samoga Stjepka Mirkovića iz VGA mogli biti povezani upravo s ovim problemima između Radonje Mirkovića i nasljednika Stjepka Mirkovića. Posljednji pronađeni spomen: pro Radognam Mirchouich uti procuratorem Symchi eius filii (24. 12. 1481.), HR-DADU, Cons. Min., vol. 21, f. 269v.

69 Ego Radogna Mirchouich confiteor quod super me et omnia mea bona pro dote et perchiuio Nicolete filie Marci Tintinich uxoris mee habui et recepi a dicto Marco socero meo mihi dante et soluente pro dote et perchiuio predictis iperperos sexcentos grossorum Ragusii (6. 2. 1465.), HR-DADU, Liber dotium, vol. 7, f. 53v; olim Marci Tintinich ... partium Radogne Mirchouich et partium Nicole Milatouich, generis dicti Marci (28. 2. 1479), HR-DADU, Cons. Min., vol. 21, f. 48; Testamentum Nicolete uxoris quondam Radogne Mirchouich dicti Cladorub (6. 7. 1482.), HR-DADU, Test. Not., vol. 24, f. 66; HR-DADU, VGA, 215-215v.

70 Nicolaus de Radogna Mircouich barberius (24. 5. 1468.), HR-DADU, Div. Not., vol. 52, f. 1; Nicola Radognich barberius (19. 4. 1469.), Isto, f. 139v; Nicola Radognich barberius (25. 5. 1469.), Isto, f. 150; Nicolaus Radognich barberius (15. 5. 1472.), Isto, vol. 56, f. 34v; Nicola Radognich barberius (24. 9. 1472.), Isto, f. 101v; Nicole Radognich barberio (28. 10. 1472.), Isto, f. 131v; Nicolaus Radognich barberius (11. 3. 1476.), Isto, vol. 60, f. 24; Simchus Radogne Mirchouich (11. 10. 1480.), HR-DADU, Cons. Min., vol. 21, f. 167; Simchus Cladorubouich (10. 7. 1481.), Isto, f. 235; Simchus Radogne Mirchouich (12. 7. 1483.), Isto, vol. 22, f. 96; Simchus Cladorubouich (15. 9. 1484.), Isto, vol. 22, f. 181v; Marusse relicte Symchi Radogne Mirchouich (9. 3. 1486.), Isto, f. 278; Symchi Cladorubouich (6. 4. 1486.), Isto, vol. 22, f. 280v; Marusse relicte Symchi Cladorubouich (22. 4. 1486.), Isto, vol. 22, f. 282v; Symonis Radogne Cladorubouich (22. 8. 1486.), Isto, vol. 23, f. 7; Marusse relicte Symchi Cladorubouich (30. 1. 1487.), Isto, f. 37; Marussa relicta Symchi Cladorubouich (6. 3. 1487.), Isto, 45v; Marussa relicta Symchi Cladorubouich (12. 3. 1487.), Isto, 47; Nicola Radogne Cladorubouich barberius (2. 1. 1488.), HR-DADU, Div. Not., vol. 68, f. 41v. Sa strane: 1494 die XV januarii Symchus Radognich contentus et confessus fuit se a contrascripto magistro Nicolao, Isto; Nichola Radognich dictus Cladorub tonsor (19. 10. 1489.), HR-DADU, Div. Canc., vol. 87, f. 23; Nicolao Radogne dicti Cladorub tonsore (16. 9. 1495.), Isto, vol. 91, f. 12; Magister Nicolaus Cladorubouich tonsor (17. 11. 1497.), HR-DADU, Isto, vol. 92b, f. 23; Magister Nicolaus Cladorubouich barberius (25. 5. 1498.), Isto, f. 138v; Nicola Cladurobouich (2. 3. 1497.), HR-DADU, Cons. Min., vol. 26, f. 5v; Magister Nicoalus Radogne Cladorub tonsor (22. 6. 1497.), HR-DADU, Div. Not., vol. 77, f. 145v; Nicole Cladorubouich barberio quod possit eleuare in altum domum suam in contrata monasterii Sancte Marie de Castello (13. 7. 1497.), HR-DADU, Cons. Min., vol. 26, f. 37v; Nicola Cladorubouich (30. 3. 1500.), Isto, f. 264; Nicolaus Radognich barberius dictus Cladorubouich (2. 3. 1501.), HR-DADU, Div. Not., vol. 80, f. 82; Nicolaus Radognich Cladorub barberius (23. 6. 1507.), Kurtović, Izvori za historiju srednjovjekovne Bosne I/1, 706; Magister Nicolaus Radognich dictus Cladorubouich et Antonius, eius filius, ambo barberii (3. 12. 1509.), HR-DADU, Div. Not., vol. 88, f. 97v; Hieronymo Nicolai barberii Cladorub (24. 7. 1515.), Isto, 792; Hieronymo Nicolai barberii Cladoruch (20. 9. 1518.), Isto, 816; Nicolao Cladorubouich barberio (13.11. 1519.), Isto, 827; Magister Nicolaus Radognich dictus Cladorubouich, barberius (27.9. 1514.), HR-DADU, Div. Not., vol. 91, f. 197v; Dominicus Nicolai Cladorobouich (30. 5. 1520.), Isto, vol. 95, f. 101; Dominici Cladorubouich (6. 7. 1525.), HR-DADU, Div. Canc., vol. 114, f. 16; Nicolai Cladorubouich (2. 8. 1526.), Isto, f. 273v; gastaldi (...) Domenico Cladorobouich” (1543.), HR-DADU, Matrikula antunina, vol. 21, 56. 
starješina Bratovštine brijača 1478., ${ }^{71}$ dok je Dominik Nikole Kladorubovića bio član ("iz pobožnosti”) lazarina (Bratovštine svetoga Lazara). ${ }^{72}$

\section{Umjesto zaključka}

Analiza pokazuje da najranije informacije o pojedinim rodovima u VGA-u predstavljaju predmet dodatnih provjera. Vlajkijeva genealogija antunina nije kronika zasnovana samo na pisanim vrelima prvoga reda, nego dijelom i rekapitulacija oblikovane usmene tradicije prema dnevnim potrebama i namjernim intervencijama iz kasnijih vremena. Mirko Pribinjić zvan Kladorup nije pripadnik plemstva, a njegov dolazak u Dubrovnik nije povezan s ubojstvom izvršenim na bosanskome vladarskom dvoru niti je on podrijetlom iz Srebrenice nego iz Cernice. Kroz pronađene informacije može se uočiti da češće spominjana Cernica svojim zapisom djelomično i sliči na zapisivanje imena Srebrenica. Svakako, onaj tko je oblikovao pokazatelje u VGA-u o Kladorubovićima u svome vremenu, neopravdano je prednost dao Srebrenici u odnosu na Cernicu.

Prostor za oblikovanje rodoslovnoga stabla Kladorubovića otvoren je i detaljnija istraživanja arhivske građe za nasljednika Radonje i Stjepka Mirkovića donijet će još veći broj informacija. Preko arhivskih vrela dobili smo informacije o tetkiću Marka Pribinjića, njegovome sinu Stjepku Mirkoviću i njegovim nasljednicima te kćeri Dominiki i njezinoj obitelji, a kojih u VGA-u nema. Prikupljeno omogućava stvaranje monografske obrade Kladorubovića.

$\mathrm{Na}$ ovome mjestu pretpostavljamo i da su određeni problemi među nasljednicima, lozi dvojice braće Stjepka i Radonje Mirkovića, bili razlogom da VGA o Kladorubovićima zapravo posjeduje informacije i prateće nedostatke istih, koje se pripremili i istaknuli nasljeđu kao povijesti svojih predaka zapravo pripadnici jače grane, nasljednici Radonje Mirkovića, a ne neopterećeni nezavisni istraživači izvorne građe.

\footnotetext{
${ }_{71}$ Ad instantiam Nichole Cladorub tonsoris castaldii fraternitatis tonsorum (5. 5. 1478.), HR-DADU, Div. Canc., vol. 78, f. 171v. O bratovštini brijača, Neda Kovačić, Medicinska vještačenja u postupcima kaznenog suda u Dubrovniku u 18. stoljeću (Zagreb: Sveučilište u Zagrebu, 2018), 36 i dalje, pristup ostvaren 28. 5. 2019. https://dr.nsk.hr/islandora/object/unidu:515/preview.

72 Domenego de Nicolo Cladorob[ovich], Štefica Curić Lenert, Nella Lonza, "Bratovština Sv. Lazara u Dubrovniku (1531-1808): osnutak, ustroj, članstvo”, Anali Dubrovnik 54 (2016), br. 1: 92.
} 


\section{Arhiv}

Hrvatska - Državni arhiv u Dubrovniku - HR-DADU, ser. 2 - Veliko vijeće (Consilium Maius)

Hrvatska - Državni arhiv u Dubrovniku - HR-DADU, ser. 3. 1, Vijeće umoljenih (Consilium Rogatorum)

Hrvatska - Državni arhiv u Dubrovniku - HR-DADU, ser. 4, Malo vijeće (Consilium Minus)

Hrvatska - Državni arhiv u Dubrovniku - HR-DADU, ser. 9, Razne isprave Notarije (Diversa Notariae)

Hrvatska - Državni arhiv u Dubrovniku - HR-DADU, ser. 10. 1, Dugovi Notarije (Debita Notariae)

Hrvatska - Državni arhiv u Dubrovniku - HR-DADU, ser. 11, Punomoći notarijata Dubrovnik (Procurae Notariae)

Hrvatska - Državni arhiv u Dubrovniku - HR-DADU, ser. 12. 1, Oporuke Notarije (Testamenta Notariae)

Hrvatska - Državni arhiv u Dubrovniku - HR-DADU, ser. 13. 1, Knjiga o ugovorima i mirazu (Liber dotium Notarie)

Hrvatska - Državni arhiv u Dubrovniku - HR-DADU, ser. 15, Razni zapisi državne kancelarije (Diversa Cancellariae)

Hrvatska - Državni arhiv u Dubrovniku - HR-DADU, ser. 21. 2, Tužbe kaznenih djela izvan grada (Lamenta de foris)

Hrvatska - Državni arhiv u Dubrovniku - HR-DADU, ser. 48.1 - Confraternitates, Matriculae, vol. 21, (Matrikula antunina)

Hrvatska - Državni arhiv u Dubrovniku - HR-DADU, 257 Obitelj Čingrija (Vlajkijeva genealogija antunina)

\section{Objavljeni izvori i literatura}

Babić, Anto. "Tradicija i istorijsko pravo u odnosima Bosne i Dubrovnika u srednjem vijeku”. U: Pristupni predavanja, prilozi i bibliografija na novite členovi na MANU. Skopje: MANU, 1974.

Benyovsky Latin, Irena; Pešorda Vardić, Zrinka; Haničar Buljan, Ivana. "Antunini na Placi: prostorni razmještaj članova Bratovštine sv. Antuna duž dubrovačke Place u 15. stoljeću”. Povijesni prilozi 37 (2018), br. 55: 57-138.

Curić Lenert, Štefica; Lonza, Nella. “Bratovština Sv. Lazara u Dubrovniku (15311808): osnutak, ustroj, članstvo”. Anali Dubrovnik 54 (2016), br. 1: 39-113. 
Ćuk, Ruža. "Dubrovačke građanske porodice poreklom iz srednjovekovne bosanske države". U: Bosna i Hercegovina od srednjeg veka do novijeg vremena. Beograd: SANU, 1995.

Dinić, Mihailo. Za istoriju rudarstva u srednjevekovnoj Srbiji i Bosni I. Beograd: SANU, 1955.

Gacović, Slavoljub. Etimologija slovenskih osnova u ojkonimiji Vidinskog sandžaka u XV i XVI veku. Zaječar: Matična biblioteka "Svetozar Marković”, 1997.

Hrabak, Bogumil. "Cernica - trg feudalne epohe u istočnoj Hercegovini”. U: Bogumil Hrabak, Iz starije prošlosti Bosne i Hercegovine, knj. IV. Beograd: Arhivar, 2008.

Kovačević-Kojić, Desanka. Srednjovjekovna Srebrenica XIV-XV vijek. Beograd: SANU, 2010.

Kovačić, Neda. Medicinska vještačenja u postupcima kaznenog suda u Dubrovniku u 18. stoljeću. Zagreb: Sveučilište u Zagrebu, 2018.

Pristup ostvaren 28.5. 2019. https://dr.nsk.hr/islandora/object/unidu:515/preview.

Kurtović, Esad. Izvori za historiju srednjovjekovne Bosne I/1 (Ispisi iz knjiga zaduženja Državnog arhiva u Dubrovniku 1365-1521). Sarajevo: ANU BiH, 2017.

Kurtović, Esad Arhivska građa za historiju srednjovjekovne Bosne (Ispisi iz knjiga kancelarije Državnog arhiva u Dubrovniku 1341-1526), 2. Sarajevo: Institut za historiju-JU Historijski arhiv Sarajevo, 2019.

Lupis, B. Vinicije. "O rodu Jakete Palmotića”. U: Hrvojka Mihanović Salopek Vinicije B. Lupis, Željezni duh: Prinos Jakete Palmotića Dionorića hrvatskoj književnoj baštini, 17-39. Zagreb; Dubrovnik: Institut društvenih znanosti Ivo Pilar, 2010.

Lupis, B. Vinicije. "Amatus Lusitanus e Didaco Pirro: due ebrei portoghesi e cerchia umanistica di Dubrovnik". U: Humanismo e Ciência: Antiguidade e Renascimento. Aveiro; Coimbra; São Paulo: UA Editora, Universidade de Aveiro; Imprensas da Universidade de Coimbra, 2015.

Marušić, Matija Matko. "Mapping housing market in late medieval Dubrovnik: The Saint Nicholas sexterium (ca. 1420-1450)". U: Mapping urban changes/Mapiranje urbanih promjena, 294-311. Zagreb: Institut za povijest umjetnosti, 2017.

Pešorda Vardić, Zrinka. "Bratimska elita: o počecima dubrovačke bratovštine sv. Antuna". U: Med Srednjo Evropo in Sredozemljem: Vojetov zbornik. Ljubljana: Založba ZRC SAZU, 2006.

Pešorda Vardić, Zrinka. U predvorju vlasti. Dubrovački antunini u kasnom srednjem vijeku. Zagreb; Dubrovnik: Zavod za povijesne znanosti HAZU u Dubrovniku; Hrvatski institut za povijest, 2012. 
Pešorda Vardić, Zrinka. "Property and Ownership in Dubrovnik’s Confraternity of St Anthony in the Late Medieval and Early Modern Ages". U: Towns and Cities of the Croatian Middle Ages: Authority and Property, 327-347. Zagreb: Hrvatski institut za povijest, 2014.

Vidović, Domagoj. "Prilog proučavanju odraza svetačkog imena Ivan u hrvatskoj antroponimiji”. Rasprave Instituta za hrvatski jezik i jezikoslovlje 35 (2009): 347-364. 